\title{
How National Institutions Shape Skilled Immigrants' Chances of Getting Hired: Evidence from Harmonised Factorial Surveys with Employers in Germany and England
}

\author{
Felix Stumpf • Andreas Damelang • Martin Abraham • \\ Sabine Ebensperger
}

Published online: 1 July 2020

(C) The Author(s) 2020

\begin{abstract}
This study provides novel insights into the institutional conditions under which skilled immigrants get hired for skilled jobs in different countries. We argue that immigrants' hiring chances depend on the interplay between institutions in sending countries, which determine the type of education that immigrants bring, and institutions in receiving countries, which shape employers' preferences for certain types of education. We develop a research design that considers this interplay and allows us to directly compare how education from sending countries with different institutional arrangements is rated by employers in two countries with widely divergent institutional contexts of reception, Germany and England. Using harmonised factorial surveys, we simulate hiring processes and evaluate the chances of German and English employers inviting foreign-educated immigrants to interviews for jobs commensurate with their education. The survey design makes it possible to experimentally vary the institutional settings in which immigrants acquired their education in the sending country, and isolate their effect on employers' ratings. Our key finding is that immigrants from sending countries with highly standardised occupationorientated education systems prevail in the hiring competition, irrespective of the education system in the receiving country.
\end{abstract}

F. Stumpf $(\triangle) \cdot$ A. Damelang $\cdot$ M. Abraham $\cdot$ S. Ebensperger

Chair of Sociology and Empirical Research Methods, Friedrich-Alexander-University

Erlangen-Nuremberg

Findelgasse 7/9, 90402 Nuremberg, Germany

E-Mail: felix.stumpf@fau.de

A. Damelang

E-Mail: andreas.damelang@fau.de

M. Abraham

E-Mail: martin.abraham@fau.de

S. Ebensperger

E-Mail: sabine.ebensperger@fau.de 
Keywords Educational systems · Foreign education · Labour market · Vignette study $\cdot$ Vocational education and training

\section{Wie nationale Institutionen die Einstellungschancen ausländischer Fachkräfte prägen - Ergebnisse harmonisierter faktorieller Surveys in Deutschland und England}

Zusammenfassung Diese Studie liefert neue Erkenntnisse zu den institutionellen Rahmenbedingungen, unter denen im Ausland ausgebildete Fachkräfte Zugang zu qualifizierten Tätigkeiten erhalten. Wir argumentieren, dass ihre Arbeitsmarktchancen von der institutionellen Ausgestaltung der Ausbildungssysteme im Herkunftsund Aufnahmeland abhängen. Diese bestimmen einerseits den Typus beruflicher Qualifikationen, die ausländische Fachkräfte mitbringen, und andererseits welche Qualifikationen Arbeitgeber bei der Stellenbesetzung erwarten. Mithilfe eines experimentellen Forschungsdesigns untersuchen wir, wie Arbeitgeber in Deutschland und England, zwei Ländern mit ganz unterschiedlich ausgestalteten beruflichen Systemen, Qualifikationen aus unterschiedlich ausgestalteten ausländischen Systemen bewerten. Für diesen Ländervergleich erheben wir in faktoriellen Surveys, mit welcher Wahrscheinlichkeit die Arbeitgeber ausländische Fachkräfte zum Vorstellungsgespräch für qualifizierte Jobs einladen. Dabei variieren wir experimentell die institutionellen Merkmale der Systeme, in denen Migranten ihre Ausbildung im Herkunftsland erworben haben, um ihre Kausaleffekte auf die Arbeitgeberentscheidungen schätzen zu können. Unsere Ergebnisse zeigen, dass Migranten aus hochgradig standardisierten und berufsspezifischen Ausbildungssystemen bevorzugt werden, und zwar unabhängig vom Ausbildungssystem des Aufnahmelands.

Schlüsselwörter Bildungssysteme · Ausländische Abschlüsse · Arbeitsmarkt • Vignettenstudie · Berufliche Ausbildung

\section{Introduction}

Globalisation and growing worker mobility have led to increasing inflows of immigrants with foreign education into national labour markets. Empirical research shows that compared with individuals with native qualifications, foreign-educated immigrants are disadvantaged in the labour market and have lower returns on education (Arbeit and Warren 2013; Kanas and Van Tubergen 2009; Zeng and Xie 2004). From a comparative perspective, it is noted that the extent to which immigrants succeed in the labour market varies across receiving countries (Ballarino and Panichella 2015, 2017; Büchel and Frick 2005; Kogan 2006; Panichella 2018). Immigrants' chances are particularly poor in countries where the education system is more vocationally orientated (Kreyenfeld and Konietzka 2002; Lancee 2016). Accordingly, it is assumed that institutional differences in education systems contribute to the cross-country differences in immigrants' labour market integration.

Across countries, education systems vary in their institutional arrangements and the types of skills they convey (Thelen 2004). In some countries, education fol- 
lows standardised occupation-orientated frameworks and provides very occupationspecific skills. In other countries, education is less specific and conveys fairly general skills such as literacy, arithmetic and other cognitive skills (e.g. Allmendinger 1989). National institutional frameworks form employers' views of education and how they use it to screen job candidates in the hiring process (Di Stasio and Van de Werfhorst 2016). In countries where education is highly standardised and occupation-orientated, employers place great emphasis on familiar occupational certificates that clearly signal the endowment with relevant occupational skills and promise a high productivity of job seekers. In countries with less occupation-specific frameworks, employers instead strongly rely on signals of trainability, such as grades.

The fact that national institutions shape the formation of skills as well as the screening behaviour of employers has some implications for the labour market integration of foreign-educated immigrants. First, the institutions in their sending country determine the type of skills that immigrants are equipped with. Given the variation in institutional arrangements of education systems, immigrants from different countries may come with different types of skills, even when they have formally comparable levels of education. Second, immigrants' chances of getting hired hinge upon how employers in the receiving country rate education acquired in the sending country. This is where the institutional context of reception comes into play.

In receiving countries with standardised occupation-specific education systems, employers prefer immigrants from similar types of systems (Damelang et al. 2019). However, such systems are rare, and therefore most immigrants lack the specific skills and educational signals that employers in these countries demand. As a result, immigrants are likely to struggle with transferring their education and be disadvantaged in the competition for skilled jobs (Damelang and Abraham 2016; Kreyenfeld and Konietzka 2002; Lancee 2016; Lancee and Bol 2017).

In receiving countries with more general educational frameworks, on the other hand, employers are used to graduates with less uniform occupational profiles; thus, one would expect that the chances of accessing skilled positions are less conditional on education of a specific type. Nonetheless, with international worker mobility on the rise, even employers in countries with more general systems have the option of hiring immigrants with standardised occupation-orientated foreign educational backgrounds. How exactly these employers act upon candidates with such education is less clear in theory.

In this research, we empirically address the question how national institutions affect the chances of employers granting foreign-educated immigrants access to skilled jobs. Our study provides a valuable contribution, because it considers the interplay between institutions in sending and receiving countries. Taking on a comparative perspective, we analyse how employers in different institutional contexts of reception respond to education acquired in different types of foreign systems. In this way, we generate new insights into why immigrants' labour market chances vary across receiving countries.

The comparison is carried out between Germany and England, two receiving countries that provide for wide institutional variation: overall, Germany has a very tight linkage between education and work (DiPrete et al. 2017) owing to its occupation-orientated education system that is marked by a high degree of vocational 
specificity and standardisation, whereas in England, education is less occupationspecific and standardised overall and provides more general skills (Maurice et al. 1986; Ryan 2001).

Our empirical strategy is to compare the likelihood of employers in these widely divergent settings hiring foreign-educated immigrants from systems of various institutional configurations for skilled positions. In harmonised factorial surveys with German and English employers, we simulate a hiring process for a skilled position as an office clerk. Respondents with responsibility for personnel are presented with vignettes describing foreign-educated candidates and asked to rate the probability that they would invite these candidates to a job interview. Across the vignettes, the institutional background of the candidates' education and other relevant characteristics vary experimentally. Such survey experiments are ideal for identifying the causal effects of candidates' characteristics on employers' ratings and consequently, they have become a state-of-the-art method of analysing employers' hiring behaviour in recent research (e.g. Auer et al. 2019; Damelang and Abraham 2016; Damelang et al. 2019; De Wolf and van der Velden 2001; Di Stasio 2014; Di Stasio and van de Werfhorst 2016; Di Stasio and Gërxhani 2015; Protsch and Solga 2017).

By employing this experimental approach in a cross-country comparison between Germany and England, we can not only disentangle how candidates' educational characteristics affect their chances of getting invited for job interviews in the two countries, but also test whether characteristics are rewarded differently depending on the interplay between educational institutions in the candidates' country of origin and the receiving country. If employers consider institutional differences when making hiring decisions, immigrants with formally comparable levels of education will have different employment opportunities in different receiving countries.

The paper is organised as follows. In the next section, we put forward theoretical arguments about how national institutions shape the screening behaviour of employers, and discuss the implications for the chances that foreign-educated immigrants get hired for skilled jobs in different countries. In the third section, we introduce our factorial survey design and data, which provide the basis for the empirical analyses. Results of the analyses are discussed in the fourth section. The paper closes with a discussion of the central findings and some concluding remarks.

\section{National Institutions and the Labour Market Prospects of Skilled Immigrants}

Human capital theory provides some well-established explanations for ethnic inequalities in the labour market. Some part of the human capital that immigrants accumulate in their country of origin is country-specific-for example, proficiency in their native language - and is therefore not transferable to the country of destination (e.g. Chiswick and Miller 2008, 2009; Friedberg 2000). Thus, following international migration, foreign education generally depreciates. Moreover, immigrants' human capital may be of lower quality and less applicable in the receiving labour market if it stems from countries with lower levels of educational and economic development. 
Beyond limitations in the transferability of human capital, one must consider limitations in the transferability of educational degrees (Lancee and Bol 2017; Damelang et al. 2019). Typically, foreign educational degrees are more difficult to decipher and may therefore send weaker signals to employers in the receiving country. In particular, we argue that the transferability of foreign degrees varies with the institutional configuration of education systems. Depending on national institutional configurations, educational profiles are more or less tailored to occupational positions in the labour market. In turn, institutional configurations determine to what extent employers pay attention to specific educational signals when making hiring decisions (Di Stasio and Van de Werfhorst 2016).

In the next sections, we first elaborate on country-specific institutional configurations and how they shape the way that employers screen job candidates. Against this background, we then discuss the implications for the hiring chances of foreigneducated immigrants.

\subsection{Institutional Variation in National Education Systems and Skill Formation}

Across countries, there is variation in the institutional configuration of education systems, resulting in cross-national differences in skill formation (Thelen 2004). In some countries, such as Denmark or Germany, systems with a strong vocational orientation are in place that provide for highly uniform occupation-specific skills, whereas in other countries, such as England or Italy, education systems are less vocation-orientated and convey fairly general skills (Breen 2005). This cross-national variation can be subsumed under two institutional dimensions of education systems: their degree of (1) occupational specificity, and (2) standardisation. ${ }^{1}$

Occupational specificity reflects the extent to which education prepares for specific occupational profiles. Systems that have a high degree of specificity focus on the teaching of the particular functional tasks carried out in occupations (Ryan 2003). Graduates from these systems are equipped with highly functional skills that make them immediately productive in the relevant occupation. For these graduates, additional on-the-job training is hardly necessary (Blossfeld 1992). Less occupationspecific education systems, on the other hand, lay greater emphasis on the teaching of general skills, such as arithmetic, literacy, general cognitive skills, basic cultural and communication skills (DiPrete et al. 2017). Therefore, graduates in more general education frameworks mainly acquire the relevant occupation-specific skills on the job (Maurice et al. 1986).

Standardisation, according to Allmendinger's classic definition (1989, p. 233), reflects "the degree to which the quality of education meets the same standards nationwide". In standardised systems, there are institutionalised rules at the country level that clearly define the skills conveyed in education. Given that educational institutions abide by these rules nationwide, there is little variation in the education

\footnotetext{
1 Another key characteristic of education systems is their level of stratification (Allmendinger 1989; Müller and Shavit 1998), that is, the extent to which they sort students with different ability levels into separate educational tracks. In our survey experiment, we do not vary the level of stratification.
} 
that individuals acquire and, thus, graduates are equipped with highly comparable skills and degrees.

In this study, we exploit the variation between the institutional configurations of two receiving countries that are known to represent widely divergent types of labour market organisation (Hall and Soskice 2001), Germany and England. Germany has a highly coordinated market economy with a particularly strong education-to-work linkage (DiPrete et al. 2017). Educational institutions collaborate with firms to provide (dual) vocational education and training that serves the specific skills that firms require. In this setting, education is highly occupation-specific and standardised, and firms' work organization for skilled jobs is closely aligned with the relevant educational profile (Marsden 2000). As a result, graduates are equipped with readily applicable sets of skills that are highly transferable across firms and ensure that graduates in the respective occupations are productive upon hiring without much additional training on the job.

England, on the other hand, is a textbook example of a liberal market economy with uncoordinated industrial relations and a looser nexus between education and jobs. The English education system predominantly conveys general skills, while occupation-specific skills are mainly acquired on the job (Maurice et al. 1986). In this framework, education is less occupation-specific and less standardised. Given the low level of coordination, employers lack incentives to contribute to collective training provision (Ryan 2001), but are prepared to train new hires on site.

\subsection{Foreign-Educated Immigrants' Chances of Getting Hired in Different Institutional Contexts}

Screening theory (Stiglitz 1975) provides our starting point for explaining how employers respond to candidates with different educational backgrounds. Prior to hiring, employers cannot observe the productivity of potential future workers. To reduce the risk of making poor hiring decisions, they screen available candidates using educational credentials and other signals that they deem relevant (Bills 2003).

Native educational credentials typically make for a functional screening device. Employers are highly familiar with their national framework of education and through frequent experience with native graduates, they have a clear perception of the skills that native credentials reflect. Drawing on this information, employers can rather reliably assess and select candidates on the basis of native educational credentials.

Screening candidates on the basis of foreign credentials, on the other hand, is less straightforward for employers. Normally, they not only have less information about foreign schemes and regulations of education but also less experience with holders of foreign credentials. They therefore remain uncertain about the skills and productivity that foreign degrees accredit.

Employers' uncertainty about foreign education in the screening process can explain part of the ethnic penalties that immigrants incur in the labour market. According to statistical theories of discrimination (Aigner and Cain 1977; Phelps 1972), one way for employers to cope with uncertainty about individual productivity is to impute information about the average productivity of groups that individuals fall 
into. If employers deem foreigners less productive on average, they may statistically discriminate against them by ascribing lower productivity to foreign individuals regardless of individual characteristics. De facto, foreign education is then devaluated in the job competition (Cain 1986).

We argue that the transferability of foreign education is determined by the institutional configuration of national education systems in sending and receiving countries. Institutions determine not only the type of education that immigrants acquire in the sending country but also the type of educational signals that employers in the receiving country value in the hiring process. In this respect, the country-specific linkages between education and work in Germany and England provide distinct opportunity structures for the integration of foreign-educated immigrants.

Given Germany's highly occupation-coordinated labour market, we expect German employers to identify suitable candidates for skilled positions by screening for occupation-specific skills that promise high productivity from the outset. Thus, immigrants have higher chances of getting hired for skilled positions if they come from systems that are similar to Germany's - that is, systems that provide standardised occupation-specific education-whereas immigrants who lack this favourable type of education are disadvantaged in the job competition. Accordingly, we advance a research hypothesis for Germany.

H1 German employers prefer foreign-educated candidates from systems that provide standardised occupation-specific education, all other things being equal.

In England, by contrast, the level of coordination in the labour market is low and educational profiles for occupations are less uniform. In this setting, employers rely less on standardised occupation-specific educational profiles in hiring decisions, but are used to providing new hires with training on the job. Accordingly, English employers are likely to place great emphasis on education as a general signal of trainability in hiring decisions to reduce training costs (Di Stasio and Van de Werfhorst 2016), whereas the specific institutional context in which these signals are obtained should prove less relevant. Intuitively, one would therefore expect English employers not to have any clear preference for education of a certain type, as opposed to employers in Germany. This expectation is summarised in the following hypothesis:

H2a English employers do not pay attention to institutional characteristics of the education systems that foreign-educated candidates come from, all other things being equal.

The differences in the institutional frameworks of Germany and England notwithstanding, it must be noted that more standardised and occupation-specific education provides employers with information that may prove beneficial in either type of system. More standardised and occupation-specific education generally conveys better information about the productivity and trainability that employers can expect from a candidate for a particular job. If a candidate's foreign education is highly standardised and occupation-specific, it clearly assures employers that the candidate is suitable for the occupation in question. From this perspective, more standardised 
and specific education may be of universal benefit, because it reduces employers' uncertainty in the assessment of foreign qualifications, irrespective of the institutional framework in the receiving country. Moreover, although English employers typically have little experience with candidates who have this type of education, they may assume that such candidates are already equipped with relevant occupational skills and therefore require less on-site training upon hiring. As a result, immigrants with standardised occupation-specific educational profiles might prevail over others in the hiring competition, both in countries with occupation-specific educational systems and in countries where training on the job is more common. Following these considerations, we can formulate an alternative hypothesis:

$H 2 b$ English employers prefer foreign-educated candidates from systems that provide standardised occupation-specific education, all other things being equal.

\section{Survey Design and Data}

To investigate how employers in Germany and England act on foreign education from different types of systems, we employ cross-nationally harmonised factorial surveys in which we simulate a hiring process for skilled jobs. The simulated hiring process concerns jobs in the skilled segment of the labour market. Foreign-educated immigrants apply for a (hypothetical) vacant position as an office clerk at the respondent's firm. In Germany, the official occupational title is "Kaufmann/-frau für Büromanagement", which is commonly referred to as "Bürokaufmann/-frau".

This occupation allows us to gather extensive and highly comparable data on the hiring chances of skilled immigrants in Germany and England for a number of reasons. First, the occupation is common across a wide variety of industries and firms in both countries. Second, the tasks that are required in this occupation are only moderately specific, especially when compared with other industrial and craft occupations. It is therefore reasonable to assume that office clerks carry out similar tasks and have highly comparable job requirements across countries. Nevertheless, we present respondents with a list of elementary tasks in this occupation to ensure that they have a shared understanding and refer to the same job profile when rating the candidates. These tasks include handling internal and external correspondence; preparing and providing documents; preparing meetings and conferences, and following up after; answering telephones, directing calls and taking messages; planning, coordinating and monitoring appointments; processing orders and invoices, and monitoring payment transactions. Third, in terms of occupational regulations, the hiring of office clerks is not conditional on having a license or any specific native degree in either of the countries, but is entirely up to employers, so that foreign-educated immigrants are generally eligible for work in this occupation. At the same time, pathways into the occupation differ across countries in accordance with our theoretical considerations. In Germany, employers typically demand the relevant occupational certificate acquired in an apprenticeship within the dual vocational education and training system (Berufenet 2018). In England, prerequisites for clerical jobs are less clearly defined. One may enter them through college courses, 
apprenticeships, working towards this role or applying directly (National Careers Service 2018).

\subsection{Factorial Survey Methodology}

Factorial surveys follow an experimental logic (Auspurg and Hinz 2015). Typically, series of vignettes that describe hypothetical situations are presented to respondents who then evaluate each description. The dimensions of these vignettes vary experimentally on a defined number of levels (Sauer et al. 2011) and vignettes are randomly assigned to respondents. Thus, one can estimate the causal effects of each vignette dimension on respondents' evaluations. This renders the method ideal for identifying causal effects of candidates' characteristics on employers' decisionmaking.

In our survey, respondents are presented with descriptions of foreign-educated job candidates with varying profiles. With respect to foreign education, the candidates have in common that they completed training as an office clerk in their country of origin. Thus, all candidates are skilled at the job in question. The variation lies in the institutional arrangement of the foreign education systems in which the candidates were trained, reflecting that they come with different types of skills. Based on the information about the foreign education system and other relevant characteristics, we ask the respondents to rate how likely they would invite the candidates for a job interview at their firm. The likelihood of inviting the candidates makes for a plausible and more realistic enquiry than the likelihood of actually hiring them, because making a hiring decision requires comprehensive information about the candidates beyond the dimensions included in the vignette descriptions.

Our survey design is cross-nationally harmonised, allowing for us to collect highly comparable experimental data from German and English respondents. These data have several advantages over conventional survey data for answering our research question:

- First and foremost, they allow us to isolate the effects of institutional features of education systems on employers' hiring decisions. By design, we ensure that employers' responses to our experimental stimuli are not biased by discrimination but reflect the institutional effects that we aim to isolate. To this end, we introduce all candidates as foreigners but do not mention their countries of origin. If we mentioned their countries of origin, they would likely evoke stereotypical beliefs about nationalities and discriminatory ratings that would suppress the effects of the dimensions we focus upon. By mimicking an anonymous application procedure, we isolate the effects of foreign education from other effects typically associated with specific citizenships.

- Second, observed relationships between candidates' characteristics and employers' decisions in our experimental data are less prone to unobserved heterogeneity bias, because the information upon which employers base their decisions is controlled very effectively by design. Conventional survey data often lack relevant variables or do not provide them in sufficient detail-for example, foreign candidates' host language proficiency at the time of hiring. In our experimental setup, 
we are able to directly manipulate the dimensions of interest while framing other relevant variables as constant. Thereby, we avoid unobserved heterogeneity biasing the effects of interest.

- Third, our data make it possible to clearly identify who is more and who is less likely to succeed in the job competition based on the candidate characteristics. In contrast to conventional survey data, which are normally restricted to candidates who succeed in getting hired, our experimental data fully disclose the characteristics and outcomes of all job candidates that employers assess.

- Fourth, varying multiple dimensions at the same time minimises the risk of social desirability bias in employers' ratings (Wallander 2009). In fact, in a study by Damelang and Abraham (2016), which also employed vignettes to simulate hiring processes, employers discriminated against foreign candidates despite being aware that they were participating in a study (for further evidence, see also Blommaert et al. 2014; Hainmüller et al. 2015). These empirical findings corroborate the notion that socially desirable answers are unlikely to occur in this setting.

\subsection{Vignette Design}

Table 1 shows the information that we manipulate in the candidate profiles. In line with the theoretical considerations, the focus lies on the institutional configuration of the foreign education system. To ensure that respondents have a shared understanding of more and less occupation-specific and standardised education systems, we spell them out as follows. In terms of occupational specificity, some candidates have acquired their education in a system where training is "highly occupation-specific, which means it is closely linked to the tasks of office clerks", whereas others come from systems where training is "rather general, which means it is only weakly linked to the tasks of office clerks". With respect to standardisation, the country's education and training system is described either as being "standardised nationwide, that is,

Table 1 Dimensions and levels of our vignettes

\begin{tabular}{ll}
\hline Dimensions & Levels \\
\hline Specificity of education system & Highly occupation-specific \\
& Rather general \\
Standardisation of education sys- & Standardised nationwide \\
tem & Not standardised nationwide \\
Selection interviews to access & Selection interviews \\
training & No selection interviews \\
Quality of education system rela- & Higher public investments in education \\
tive to the receiving country & About the same public investments in education \\
& Lower public investments in education \\
Age, work experience & 21 years old, no work experience \\
& 23 years old, 2 years of work experience \\
& 30 years old, 9 years of work experience \\
Third-party experience & Positive experience of other employers in the receiving country \\
& No experience of other employers in the receiving country \\
\hline
\end{tabular}


there are uniform training regulations", or "not standardised nationwide, that is, there are no uniform training regulations".

The vignette description also indicates whether or not access to training programmes in a system is regulated by selection interviews, and the overall quality of the education system. Educational quality is approximated by the level of public investments in education and reflects a higher, about the same, or lower level than in Germany or England respectively. For a more realistic hiring scenario and to gain further insights into relevant characteristics, the vignettes provide the respondents with additional information about the candidates' age, work experience and thirdparty experience. Candidates are aged 21 and yet to accumulate work experience, aged 23 with 2 years' experience or aged 30 with 9 years' experience. Third-party experience varies with respect to whether or not other employers in Germany or England have already reported a positive experience with office clerks from the candidates' country of origin.

Whereas the vignette dimensions vary experimentally on these levels, other relevant factors are held constant throughout. The education of the candidates formally matches the job in question, as they have all completed training as an office clerk in the sending country with good grades. We present the respondents with female candidates only, because office clerk is a predominantly female occupation (see Statistisches Bundesamt 2018; Office for National Statistics 2018) and hiring decisions might be driven by gender stereotyping. Moreover, we consider that when

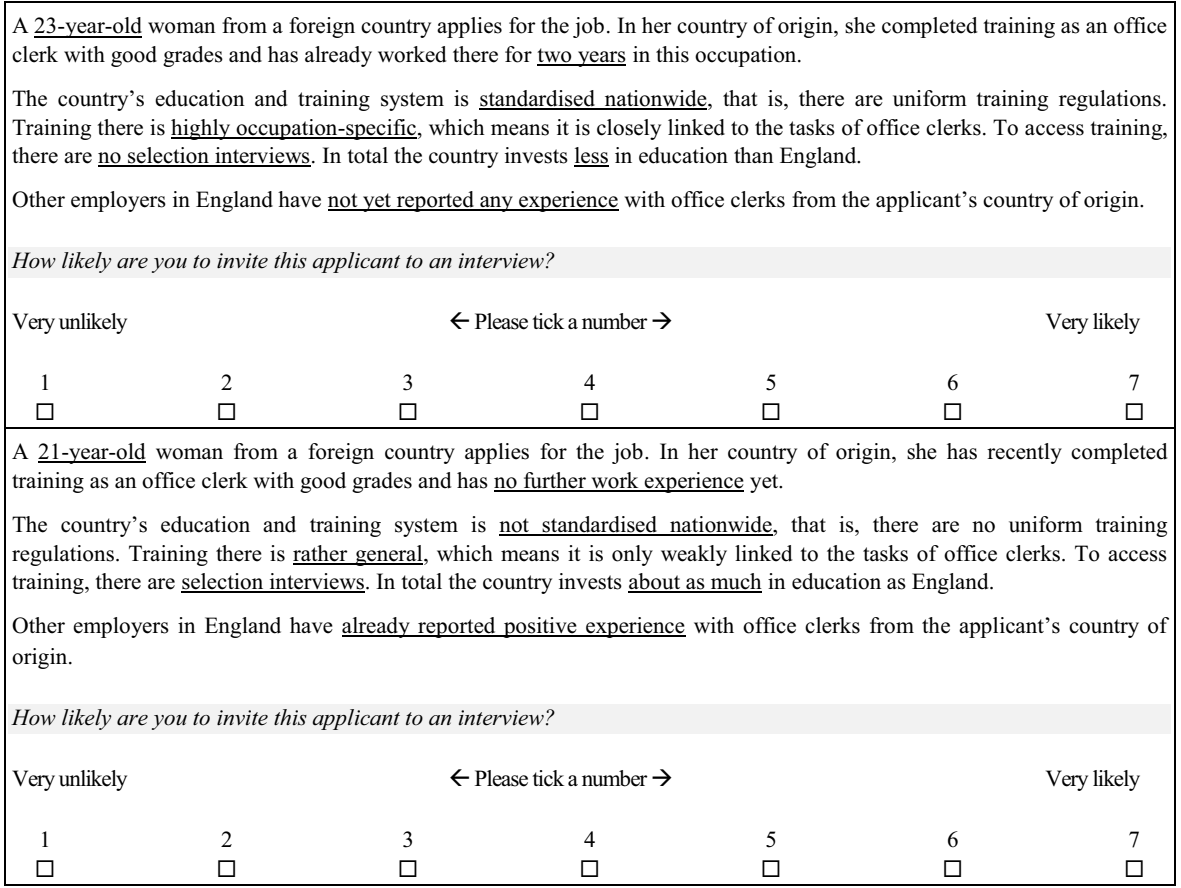

Note: Underlining highlights dimensions that vary experimentally

Fig. 1 Examples of vignettes presented to respondents in England 
assessing foreign candidates, employers may presume culture shocks, legal barriers and insufficient host language proficiency to work as an office clerk. To avoid unobserved heterogeneity in these respects, we stipulate in an introduction to the vignettes some general information that applies to all candidates. We inform respondents that each candidate immigrated about 6 months ago and is entitled to live and work in the receiving country indefinitely, and that each candidate is operationally proficient in the host language and has dependable grammar and spelling skills.

The vignette design yields a universe of 144 distinct candidate profiles $(2 * 2 * 2 * 3 *$ $3 * 2$ ). From these, we drew a D-efficient sample of 72 (with a D-efficiency of 99.89), and randomly compiled nine decks of eight candidates. The candidates within the decks come in random order. Each respondent was randomly assigned one of these sets containing eight candidates for evaluation. For each candidate, respondents rated on a scale from 1 "very unlikely" to 7 "very likely" how likely they are to invite her to an interview. We presented the candidates sequentially and retrieved the ratings one by one, so that respondents evaluated only one candidate at a time. Examples of how the candidates and their educational profiles were presented in the survey are shown in Fig. 1.

\subsection{Data Collection and Respondent Sample}

We collected our data using samples of respondents from online panels. Sampling from online panels has become a common strategy for experimental surveys, because researchers can assign treatments to the respondents completely randomly and strongly rely on the internal validity of their findings. Several related studies that employ factorial surveys have successfully applied this approach over the last years (among others, Czymara and Schmidt-Catran 2016; Kootstra 2016; Weinberg et al. 2014).

We relied on panels of the Norstat Group (www.norstat.de), a commercial provider that maintains very large and demographically balanced panels for several countries and offers sampling based on cross-nationally harmonised data. Individuals cannot register for the panels themselves but are actively recruited by Norstat through various channels. During the recruitment process, Norstat retrieves background information from the panellists and updates this information on a regular basis.

From these panels, we selected suitable subsamples for our survey in Germany and England. We collected data from 70 respondents in each country, providing us with a total of 1120 candidate ratings for analysis. The German and English surveys were carried out simultaneously in November 2018. We only invited panellists who were currently working, be it as an employee or self-employed, in jobs with responsibility for personnel to participate in our survey.

Beyond adequate sampling, we took a series of measures to ensure that our simulated hiring process yields high-quality data. It is of paramount importance that the respondents read the instructions carefully and judge each candidate conscientiously. We ensured this by applying thorough checks during the presentation of the candidates. The checks were conducted in disguise, as we included an additional profile in the series of candidates and in the description requested the respondents to 
Table 2 Composition of the respondent samples

\begin{tabular}{llll}
\hline & Countries pooled & Germany & England \\
\hline Number of respondents & 140 & 70 & 70 \\
Respondent characteristics & & & \\
Sex (\%) & & & \\
Female & 23.6 & 32.9 & 14.3 \\
Male & 76.4 & 67.1 & 85.7 \\
Age (mean) & 47.1 & 46.1 & 48.1 \\
Native-born (\%) & 92.1 & 95.7 & 88.6 \\
Highest professional qualification (\%) & & & \\
None & 0.7 & 1.4 & 0.0 \\
Secondary education (non-vocational) & 5.7 & 2.9 & 8.6 \\
Secondary education (vocational) & 35.0 & 45.7 & 24.3 \\
Tertiary education (BA) & 30.0 & 14.3 & 45.7 \\
Tertiary education (MA or similar and higher) & 28.6 & 35.7 & 21.4 \\
Form of employment (\%) & & & \\
Employed & 91.4 & 91.4 & 91.4 \\
Self-employed & 8.6 & 8.6 & 8.6 \\
Firm characteristics & & & \\
Firm size in categories (\%) & & & \\
1-9 & 11.4 & 12.9 & 10.0 \\
10-49 & 21.4 & 24.3 & 18.6 \\
50-249 & 30.0 & 27.1 & 32.9 \\
250+ & 37.1 & 35.7 & 38.6 \\
Currently looking for office clerks (\%) & 25.0 & 22.9 & 27.1 \\
Experienced with foreign-educated employees & 49.3 & 54.3 & 44.3 \\
(\%) & & & \\
\hline
\end{tabular}

tick a particular score. If the respondent did not tick the requested score, the survey was terminated immediately. Respondents could only answer the survey once.

With the retrieved data, we ran extensive robustness analysis. In particular, we followed Kootstra (2016) and re-estimated our empirical models excluding respondents who rated the candidates in under $10 \mathrm{~s}$ per vignette to address potential bias from low involvement in the hiring simulation. Results obtained from these models are highly comparable with those obtained with the full sample, suggesting that the quality of response in our data is high.

Table 2 presents some descriptive statistics of our samples. Overall, roughly three quarters of our respondents are men (76\%), with a more balanced sex composition in Germany (67\%) than in England (86\%). Respondents in both countries are of similar age (approximately 47 years) and mostly native-born, with a somewhat higher share of natives in the German (96\%) than in the English sample (89\%). In Germany, about half of the respondents have vocational education and training, the other half having qualifications from tertiary education. In the English sample, Bachelor's degrees are more common and accordingly, two-thirds of respondents have tertiary education. Nine out of 10 respondents work as employees, leaving 1 in 10 self-employed. 
Their firms have a median size of 100 employees in Germany and 162 employees in England. Roughly one-quarter of the German and English firms were looking for office clerks at the time of the survey, and approximately half of the firms had already gained experience with foreign-educated employees.

\section{Results}

In this section, we present and compare the empirical findings from the hiring simulations in Germany and England. Overall, the likelihood that respondents would invite the candidates to a job interview is very similar in the two country samples. On the provided scale from 1 to 7 , candidates receive an average rating of 4.82 in Germany, and 4.64 in England.

In the following, we apply regression analyses to identify the causal effects of institutional configurations of foreign education systems and other vignette dimensions on respondents' ratings. Our data consist of eight vignette ratings per respondent and, thus, observations are nested within respondents. We therefore rely on multilevel regression models, which account for the hierarchical data structure that emerges from factorial surveys (Auspurg and Hinz 2015).

In a first step, we estimate one model for Germany and one model for England using the same specification but country-specific data. These models include the dimensions that varied in the vignettes and additional controls for relevant characteristics at the respondent level, namely firm size, whether the firm is currently looking for office clerks, whether the firm has experience with foreign-educated employees and whether the respondent is native-born. Moreover, we include respondents' sex, age and education. In a second step, we pool the German and English data and specify a third model in which each vignette dimension interacts with a country dummy. These interactions allow us to observe any systematic differences in the effects of the vignette dimensions between Germany and England. In this way, we can test whether employers in the two countries put different emphasis on institutional characteristics of foreign education systems.

Table 3 shows the results obtained from the separate regressions for Germany and England. They indicate that in both countries, the institutional characteristics of foreign education systems play a significant role in how employers rate foreigneducated candidates. Results for Germany are in line with the expectations stipulated in H1: German employers prefer foreign-educated immigrants that come from standardised and occupation-specific systems. They are on average 0.29 points more likely to interview candidates who have completed training that is closely linked to the tasks of office clerks than candidates with more general education, and 0.39 points more likely to invite candidates whose education abides by nationwide standards than candidates with non-standardised education.

The results for England follow a similar pattern, which is in favour of $\mathrm{H} 2 \mathrm{~b}$ rather than H2a: just like the German employers, English employers also favour foreign education that is standardised and occupation-specific. On average, they rate immigrants with education from highly occupation-specific systems 0.61 points better than immigrants with more general education. Likewise, the chances that English 
Table 3 Effects of vignette dimensions on the likelihood that foreign-educated candidates are invited to a job interview; random intercept models, regression coefficients

\begin{tabular}{|c|c|c|c|c|}
\hline & Germany & & England & \\
\hline $\begin{array}{l}\text { Highly occupation-specific education } \\
\text { system (ref.: rather general) }\end{array}$ & 0.293 & $(0.086)^{* * *}$ & 0.607 & $(0.087)^{* * *}$ \\
\hline $\begin{array}{l}\text { Standardised education system (ref.: not } \\
\text { standardised) }\end{array}$ & 0.388 & $(0.086)^{* * *}$ & 0.341 & $(0.087)^{* * *}$ \\
\hline $\begin{array}{l}\text { Selection interviews to access training } \\
\text { (ref.: no selection interviews) }\end{array}$ & 0.152 & $(0.086)$ & 0.089 & $(0.086)$ \\
\hline \multicolumn{5}{|c|}{ Quality of education system (ref.: about the same public investments) } \\
\hline Higher public investments & 0.018 & $(0.107)$ & 0.050 & $(0.108)$ \\
\hline Lower public investments & -0.340 & $(0.107)^{* * *}$ & -0.198 & $(0.107)$ \\
\hline \multicolumn{5}{|c|}{ Age, work experience (ref.: 21 years old, no work experience) } \\
\hline 23 years old, 2 years' work experience & 0.630 & $(0.106)^{* * *}$ & 0.645 & $(0.105)^{* * *}$ \\
\hline 30 years old, 9 years' work experience & 0.965 & $(0.107)^{* * *}$ & 1.119 & $(0.108)^{* * *}$ \\
\hline $\begin{array}{l}\text { Positive third-party experience (ref.: no } \\
\text { third-party experience) }\end{array}$ & 0.550 & $(0.086)^{* * *}$ & 0.829 & $(0.086)^{* * *}$ \\
\hline \multicolumn{5}{|l|}{ Firm size in categories (ref.: 1-9) } \\
\hline $10-49$ & -0.359 & $(0.373)$ & -0.253 & $(0.436)$ \\
\hline $50-249$ & -0.056 & $(0.380)$ & -0.191 & $(0.426)$ \\
\hline $250+$ & 0.443 & $(0.381)$ & -0.286 & $(0.461)$ \\
\hline \multicolumn{5}{|l|}{ Currently looking for office clerks (ref.: yes) } \\
\hline No & 0.237 & $(0.285)$ & -0.089 & $(0.321)$ \\
\hline Don't know & 0.211 & $(0.439)$ & 0.668 & $(0.588)$ \\
\hline $\begin{array}{l}\text { Experienced with foreign educated em- } \\
\text { ployees }\end{array}$ & -0.085 & $(0.244)$ & 0.261 & $(0.265)$ \\
\hline Native-born & -1.023 & $(0.564)$ & 0.465 & $(0.406)$ \\
\hline Male & -0.150 & $(0.280)$ & -0.204 & $(0.326)$ \\
\hline \multicolumn{5}{|l|}{ Age (ref.: 20-39) } \\
\hline $40-49$ & 0.333 & $(0.287)$ & -0.367 & $(0.354)$ \\
\hline $50-59$ & 0.281 & $(0.312)$ & -0.229 & $(0.371)$ \\
\hline $60+$ & 0.906 & $(0.395)^{*}$ & -0.628 & $(0.399)$ \\
\hline n.a. & -0.686 & $(0.487)$ & -0.109 & $(0.420)$ \\
\hline Tertiary education (ref.: secondary) & 0.042 & $(0.234)$ & 0.063 & $(0.240)$ \\
\hline n.a. & -0.190 & $(0.935)$ & - & - \\
\hline Constant & 4.315 & $(0.752)^{* * *}$ & 3.316 & $(0.765)^{* * *}$ \\
\hline $\begin{array}{l}\text { Variance of level-two errors (Respondent } \\
\text { level) }\end{array}$ & 0.589 & $(0.122)$ & 0.634 & $(0.129)$ \\
\hline Variance of level-one errors (Residuals) & 1.026 & $(0.066)$ & 1.034 & $(0.066)$ \\
\hline Log likelihood & -861.954 & & -866.020 & \\
\hline$N$ vignettes & 8 & & 8 & \\
\hline$N$ respondents & 70 & & 70 & \\
\hline$N$ vignettes $\times$ respondents & 560 & & 560 & \\
\hline
\end{tabular}

Coefficients obtained from random-intercept models; standard errors in parentheses

DV: Likelihood that a foreign-educated applicant is invited to a job interview (1 "Very unlikely" to 7 "Very likely")

$* * * p<0.001, * * p<0.01, * p<0.05$ 
Table 4 Effects of vignette dimensions on the likelihood that foreign-educated candidates are invited to a job interview; random intercept model with country interactions, regression coefficients

\begin{tabular}{|c|c|c|}
\hline Germany (ref.: England) & 0.472 & $(0.245)$ \\
\hline $\begin{array}{l}\text { Highly occupation-specific education system (ref.: } \\
\text { rather general) }\end{array}$ & 0.607 & $(0.087)^{* * *}$ \\
\hline $\begin{array}{l}\text { Highly occupation-specific education sys- } \\
\text { tem } \times \text { Germany }\end{array}$ & -0.315 & $(0.123)^{* *}$ \\
\hline Standardised education system (ref.: not standardised) & 0.341 & $(0.087)^{* * *}$ \\
\hline Standardised education system $\times$ Germany & 0.047 & $(0.122)$ \\
\hline $\begin{array}{l}\text { Selection interviews to access training (ref.: no selec- } \\
\text { tion interviews) }\end{array}$ & 0.089 & $(0.086)$ \\
\hline Selection interviews to access training $\times$ Germany & 0.062 & $(0.122)$ \\
\hline \multicolumn{3}{|c|}{ Quality of education system (ref.: about the same public investments) } \\
\hline Higher public investments & 0.047 & $(0.107)$ \\
\hline Lower public investments & -0.199 & $(0.106)$ \\
\hline \multicolumn{3}{|l|}{ Quality of education system $\times$ Germany } \\
\hline Higher public investments $\times$ Germany & -0.029 & $(0.152)$ \\
\hline Lower public investments $\times$ Germany & -0.140 & $(0.151)$ \\
\hline \multicolumn{3}{|c|}{ Age, work experience (ref.: 21 years old, no work experience) } \\
\hline 23 years old, 2 years' work experience & 0.644 & $(0.105)^{* * *}$ \\
\hline 30 years old, 9 years' work experience & 1.118 & $(0.107)^{* * *}$ \\
\hline \multicolumn{3}{|l|}{ Age, work experience $\times$ Germany } \\
\hline 23 years old, 2 years of work experience $\times$ Germany & -0.013 & $(0.149)$ \\
\hline 30 years old, 9 years' work experience $\times$ Germany & -0.145 & $(0.152)$ \\
\hline $\begin{array}{l}\text { Positive third-party experience (ref.: no third-party } \\
\text { experience) }\end{array}$ & 0.829 & $(0.086)^{* * *}$ \\
\hline Positive third-party experience $\times$ Germany & -0.279 & $(0.122)^{*}$ \\
\hline \multicolumn{3}{|l|}{ Firm size in categories (ref.: 1-9) } \\
\hline $10-49$ & -0.278 & $(0.298)$ \\
\hline $50-249$ & 0.037 & $(0.291)$ \\
\hline $250+$ & 0.236 & $(0.302)$ \\
\hline \multicolumn{3}{|l|}{ Currently looking for office clerks (ref.: yes) } \\
\hline No & 0.016 & $(0.216)$ \\
\hline Don't know & 0.491 & $(0.364)$ \\
\hline Experienced with foreign-educated employees & 0.179 & $(0.179)$ \\
\hline Native-born & 0.166 & $(0.327)$ \\
\hline Male & -0.185 & $(0.213)$ \\
\hline \multicolumn{3}{|l|}{ Age (ref.: 20-39) } \\
\hline $40-49$ & 0.125 & $(0.231)$ \\
\hline $50-59$ & 0.151 & $(0.246)$ \\
\hline $60+$ & 0.125 & $(0.280)$ \\
\hline n.a. & -0.276 & $(0.331)$ \\
\hline Tertiary education (ref.: secondary) & 0.132 & $(0.173)$ \\
\hline n.a. & -0.248 & $(0.981)$ \\
\hline Constant & 3.059 & $(0.438)^{* * *}$ \\
\hline Variance of level-two errors (Respondent level) & 0.723 & $(0.102)$ \\
\hline
\end{tabular}


Table 4 (Continued)

\begin{tabular}{ll}
\hline Variance of level-one errors (Residuals) & $(0.047)$ \\
Log likelihood & -1737.821 \\
$N$ vignettes & 8 \\
$N$ respondents & 140 \\
$N$ vignettes $\times$ respondents & 1120 \\
\hline
\end{tabular}

Coefficients obtained from random intercept models; standard errors in parentheses

DV: Likelihood that a foreign-educated applicant is invited to a job interview (1 "Very unlikely" to 7 "Very likely")

$* * * p<0.001, * * p<0.01, * p<0.05$

employers would interview a candidate are 0.34 points higher for those from standardised than those from non-standardised foreign education systems. On the whole, these findings reflect the notion that the chances of foreign-educated immigrants getting hired for skilled jobs strongly depend on the institutional configuration of education systems in the sending country.

The remaining characteristics of foreign education systems have less pronounced effects. Selection interviews that govern access to training in foreign systems do not play any significant role in the chances of getting invited. With respect to the overall quality of foreign education systems, the results show that candidates who come from countries with higher investments in education are rated similar to candidates from countries where the level of investment is similar to Germany, or England respectively. Nonetheless, educational quality appears to matter, given that candidates from countries with lower public investments in education receive lower ratings in both countries. Although this finding is not statistically significant in England, the patterns suggest that both German and English employers tend to penalise candidates from lower-quality education systems, whereas they hardly reward candidates from higher-quality systems.

With respect to candidates' individual characteristics, age and work experience have a strong impact on the likelihood of getting invited for an interview in both countries. The youngest candidates who are just starting their career are significantly less likely to receive an invitation than older and more experienced candidates. Given their lack of work experience, they fall behind candidates with 2 or 9 years' experience by up to roughly one scale point in both countries.

Moreover, chances that foreign-educated candidates get invited substantially improve when there is positive experience of other parties. In line with rational herding (e.g. Banerjee 1992; Oberholzer-Gee 2008), respondents in Germany and England rate a given job candidate significantly better when other employers in the country have already reported positive experience with workers of the same origin.

Finally, we provide statistical evidence whether employers in Germany and England weight the various dimensions differently. Table 4 reports the results from the pooled model in which the experimental stimuli interact with a country dummy. These interactions corroborate the notion that the advantages that come with the standardisation of foreign education are of similar size in the two countries; however, the benefits of occupational specificity differ significantly between the two countries. English employers reward highly occupation-specific education 0.32 points higher 
than German employers and, thus, the benefit of specificity is about twice as large in England as it is in Germany. Likewise, the benefit of a positive third-party experience is 0.28 points higher in England. The latter is consistent with the theoretical assumption that owing to institutional differences, employers assign a different value to screening devices. Because credentials play a minor role in England, employers rely more on alternative sources of information, such as third-party experience. The country interactions with the remaining vignette dimensions indicate no statistically significant differences, reflecting that employers in Germany and England put similar emphasis on these dimensions.

\section{Discussion and Conclusion}

This paper started from the premise that the value of immigrants' foreign education depends on the interplay between institutions in sending and receiving countries. Institutions in the sending country determine the type of education that immigrants bring, and institutions in the receiving country shape employers' preferences for certain types of (foreign) education. We develop a research design that considers both and allows us to directly compare how education from sending countries with different institutional arrangements is rated by employers in different institutional contexts of reception. Using harmonised factorial surveys, we simulate hiring processes with employers in Germany and England, and evaluate the chances that they invite foreign-educated immigrants to interviews for jobs that correspond with their foreign education.

Our key finding is that the institutional characteristics of education in the sending country strongly affect the transferability of foreign qualifications to Germany and England. Despite the widely divergent institutional linkages between education and jobs in Germany and England, employers in both countries prefer foreign-educated immigrants with standardised and occupation-specific profiles. This is plausible, because occupation-orientated education not only assures employers in Germany that candidates are equipped with the relevant occupational skills that they are looking for, but also assures employers in England that a candidate is very likely to be trainable in the respective occupation. As a result, foreign-educated immigrants from such education systems have better hiring chances, regardless of the institutional framework in the receiving country.

Additional analyses reveal that the extent to which immigrants benefit from occupation-specific education in the sending country varies across receiving countries. Notably, English employers reward occupation-specific qualifications to a greater extent than German employers. This differential can be explained by the fact that English employers are prepared to train candidates on the job anyway and, thus, they particularly strongly respond to occupation-oriented education as a signal of high trainability in the respective occupation. German employers, on the other hand, might expect that candidates with occupation-oriented foreign education will still require some additional training to adapt to the specific occupational profile in Germany. 
While our survey design makes it possible to experimentally vary the institutional settings in which immigrants acquired their education in the sending country and isolate their effect on employers' ratings in Germany and England, a few remarks must be passed regarding its limitations. First, our findings are obviously not based on factual hiring behaviour but simulated hiring processes in factorial surveys. One may question whether employers' stated intentions to hire in a hypothetical scenario validly predict their hiring decisions in reality. Recent studies that have validated vignette experiments against real-world behaviour provide evidence for a close nexus between the response to vignettes and factual decisions (e.g. Hainmüller et al. 2015).

Second, this study is aimed at providing a direct test of the extent to which institutional differences contribute to the devaluation of foreign education and statistical discrimination against foreign workers that is regularly observed in receiving labour markets. Accordingly, we designed vignettes that allow for us to scrutinize how institutional characteristics of the education system in the sending country affect employers' decision making. By withholding the names of the sending countries, we mimic an anonymous application procedure that allows us to rule out countryspecific stereotyping. We do acknowledge that to date, applications in real-world hiring procedures are often not anonymous and information about institutional configurations is not necessarily readily observable for employers. In this respect, the candidate profiles in the vignettes may provide employers with more information about foreign education than would normally be available. However, with national skill shortages on the one hand and the ongoing internationalisation of labour markets on the other, collecting information about foreign education systems will become all the more important for employers in securing a supply of skilled labour in the foreseeable future. To identify foreign-educated candidates with suitable profiles, employers in Europe can already rely on information provided by supranational qualification frameworks and initiatives that make transparent the differences and similarities between national qualifications of various types and levels (European Centre for the Development of Vocational Training 2018). In addition, as employers accumulate and share their experience with skilled immigrants, they will also gain a better understanding of the variation in education systems and adjust their hiring behaviour accordingly.

Third, by focusing on office clerks, we zoom in on a typical and frequently practiced occupation in the intermediate-skilled segment of the labour market. Although this occupation can be found in almost every economic sector, transferring our results to other occupations would surely be premature. We expect that institutional differences will be less important in occupations that demand substantial amounts of firm-specific human capital, in which employers are required to make considerable investments in the on-site training of new hires, irrespective of their training background.

To conclude, this study is one of the few in inequality research that consider cross-country differences in educational institutions (e.g. Ebner and Helbling 2016; Lancee 2016) and the interplay between institutions in sending and receiving countries (e.g. Damelang et al. 2019). By taking on a comparative perspective across receiving countries, we provide novel insights into the institutional conditions that make it more or less likely that employers grant immigrants access to skilled jobs 
in accordance with foreign education. We show that immigrants from sending countries with highly standardised occupation-orientated education systems prevail in the hiring competition, irrespective of the education system in the receiving country. With this finding, we contribute to the comparative stratification literature and further highlight that national institutions play a crucial role in the labour market integration of skilled immigrants in different countries.

Funding This work was supported by the German Research Foundation (grant number AB 111/9-2 and DA 1654/1-2).

Funding Open Access funding provided by Projekt DEAL.

Open Access This article is licensed under a Creative Commons Attribution 4.0 International License, which permits use, sharing, adaptation, distribution and reproduction in any medium or format, as long as you give appropriate credit to the original author(s) and the source, provide a link to the Creative Commons licence, and indicate if changes were made. The images or other third party material in this article are included in the article's Creative Commons licence, unless indicated otherwise in a credit line to the material. If material is not included in the article's Creative Commons licence and your intended use is not permitted by statutory regulation or exceeds the permitted use, you will need to obtain permission directly from the copyright holder. To view a copy of this licence, visit http://creativecommons.org/licenses/by/4. $0 /$.

\section{References}

Aigner, Dennis J., and Glen G. Cain. 1977. Statistical theories of discrimination in labor markets. Industrial and Labor Relations Review 30:175-187.

Allmendinger, Jutta. 1989. Educational systems and labor market outcomes. European Sociological Review 5:231-250.

Arbeit, Caren A., and John R.Warren. 2013. Labor market penalties for foreign degrees among college educated immigrants. Social Science Research 42:852-871.

Auer, Daniel, Giuliano Bonoli, Flavia Fossati and Fabienne Liechti. 2019. The matching hierarchies model. Evidence from a survey experiment on employers' hiring intent regarding immigrant applicants. International Migration Review 53:90-121.

Auspurg, Katrin, and Thomas Hinz. 2015. Factorial survey experiments. Series Quantitative Applications in the Social Sciences. $175^{\text {th }}$ Thousand Oaks CA: Sage.

Ballarino, Gabriele, and Nazareno Panichella. 2015. The occupational integration of male migrants in Western European countries. Assimilation or persistent disadvantage? International Migration 53:338-352.

Ballarino, Gabriele, and Nazareno Panichella. 2017. The occupational integration of migrant women in Western European labor markets. Acta Sociologica 61:126-142.

Banerjee, Abhijit. 1992. A simple model of herd behaviour. Quarterly Journal of Economics 107:797-817.

Berufenet. 2018. https://berufenet.arbeitsagentur.de/berufenet/faces/index?path=null/kurzbeschreibung/ zugangzurtaetigkeit\&dkz=123266 (Accessed: 14 December 2018).

Bills, David B. 2003. Credentials, signals and screens: Explaining the relationship between schooling and job assignment. Review of Educational Research 73:441-69

Blommaert, Lieselotte, Marcel Coenders and Frank van Tubergen. 2014. Discrimination of Arabic-named applicants in the Netherlands. An internet-based field experiment examining different phases in online recruitment procedures. Social Forces 92:957-82.

Blossfeld, Hans-Peter. 1992. Is the German dual system a model for a modern vocational training system? A cross national comparison of how different systems of vocational training deal with the changing occupational structure. International Journal of Comparative Sociology 33:168-181.

Breen, Richard. 2005. Explaining cross-national variation in youth unemployment. Market and institutional factors. European Sociological Review 21:125-134.

Büchel, Felix, and Joachim R. Frick. 2005. Immigrants' economic performance across Europe-does immigration policy matter? Population Research and Policy Review 24:175-212.

Cain, Glen G. 1986. The economic analysis of labor market discrimination. A survey. In Handbook of Labor Economics, eds. Orley Ashenfelter and Richard Layard, 1:693-781. Amsterdam: Elsevier. 
Chiswick, Barry R., and Paul W. Miller. 2008. Why is the payoff to schooling smaller for immigrants? Labour Economics 15:1317-40

Chiswick, Barry R., and Paul W. Miller. 2009. The international transferability of immigrants' human capital skills. Economics of Education Review 28:162-169.

Czymara, Christian S., and Alexander W. Schmidt-Catran. 2016. Wer ist in Deutschland willkommen? Eine Vignettenanalyse zur Akzeptanz von Einwanderern. Kölner Zeitschrift für Soziologie und Sozialpsychologie 68:193-227.

Damelang, Andreas, and Martin Abraham. 2016. You can take some of it with you! A vignette study on the acceptance of foreign vocational certificates and ethnic inequality in the German labor market. Zeitschrift für Soziologie 45:91-106.

Damelang, Andreas, Martin Abraham, Sabine Ebensperger and Felix Stumpf. 2019. The hiring prospects of foreign-educated immigrants. A factorial survey among German employers. Work, Employment and Society 33:739-758.

De Wolf, Inge, and Rolf van der Velden. 2001. Selection processes for three types of academic jobs. An experiment among Dutch employers of social sciences graduates. European Sociological Review 17:317-330.

DiPrete, Thomas A., Christina C. Eller, Thijs Bol and Herman G. Van de Werfhorst. 2017. School-to-work linkages in the United States, Germany, and France. American Journal of Sociology 122:1869-1938.

Di Stasio, Valentina. 2014. Education as a signal of trainability. Results from a vignette study with Italian employers. European Sociological Review 30:796-809.

Di Stasio, Valentina, and Klarita Gërxhani. 2015. Employers' social contacts and their hiring behavior in a factorial survey. Social Science Research 51:93-107.

Di Stasio, Valentina, and Herman G. Van de Werfhorst. 2016. Why does education matter to employers in different institutional contexts? A vignette study in England and the Netherlands. Social Forces 95:77-106.

Ebner, Christian, and Marc Helbling. 2016. Social distance and wage inequalities for immigrants in Switzerland. Work, Employment and Society 30:436-454.

European Centre for the Development of Vocational Training (CEDEFOP). 2018. Briefing Note: Qualifications Frameworks in Europe 2017 Developments. http://www.cedefop.europa.eu/files/9127_en.pdf (Accessed: 14 December 2018).

Friedberg, Rachel M. 2000. You can't take it with you? Immigrant Assimilation and the Portability of Human Capital. Journal of Labor Economics 18:221-251.

Hainmüller, Jens, Dominik Hangartner and Teppei Yamamoto. 2015. Validating vignette and conjoint survey experiments against real-world behavior. Proceedings of the Nation Academy of Sciences 112:2395-2400.

Hall, Peter A., and David W. Soskice. 2001. Varieties of Capitalism. The Institutional Foundations of Comparative Advantage. Oxford: Oxford University Press.

Kanas, Agnieszka, and Frank Van Tubergen. 2009. The impact of origin and host country schooling on the economic performance of immigrants. Social Forces 88:893-916.

Kogan, Irena. 2006. Labor markets and economic incorporation among recent immigrants in Europe. Social Forces 85:697-721.

Kootstra, Anouk. 2016. Deserving and undeserving welfare claimants in Britain and the Netherlands. Examining the role of ethnicity and migration status using a vignette experiment. European Sociological Review 32: 325-338.

Kreyenfeld, Michaela, and Dirk Konietzka. 2002. The performance of migrants in occupational labour markets. European Societies 4:53-78.

Lancee, Bram. 2016. The negative side effects of vocational education: A cross-national analysis of the relative unemployment risk of young non-Western immigrants in Europe. American Behavioral Scientist 60:659-679.

Lancee, Bram, and Thjis Bol. 2017. The transferability of skills and degrees. Why the place of education affects immigrant earnings. Social Forces 96:691-716.

Marsden, David. 2000. A theory of job regulation, the employment relationship, and the organization of labour institutions. Industrielle Beziehungen 7:320-347.

Maurice, Marc, François Sellier and Jean-Jacques Silvestre. 1986. The social foundations of industrial power. A comparison of France and Germany. Cambridge, MA: MIT Press.

Müller, Walter, and Yossi Shavit. 1998. The institutional embeddedness of the stratification process. A comparative study of qualifications and occupations in thirteen countries. In From school to work. A comparative study of educational qualifications and occupational destinations, eds. Yossi Shavit and Walter Müller, 1-48. Oxford: Clarendon Press. 
National Careers Service. 2018. https://nationalcareers.service.gov.uk (Accessed: 14 December 2018).

Oberholzer-Gee, Felix. 2008. Nonemployment stigma as rational herding: A field experiment. Journal of Economic Behavior \& Organization 65:642-669.

Office of National Statistics. 2018. Dataset: EMP04: Employment by occupation. https:/www.ons.gov.uk/ employmentandlabourmarket/peopleinwork/employmentandemployeetypes/datasets/employmentby occupationemp04 (Accessed: 27 November 2018).

Panichella, Nazareno. 2018. Economic crisis and occupational integration of recent immigrants in Western Europe. International Sociology 33:64-85.

Phelps, Edmund S. 1972. The statistical theory of racism and sexism. American Economic Review 62:659-661.

Protsch, Paula, and Heike Solga. 2017. Going across Europe for an apprenticeship? A factorial survey experiment on employers' hiring preferences in Germany. Journal of European Social Policy 27:387-399.

Ryan, Paul. 2001. The school-to-work transition: A cross-national perspective. Journal of Economic Literature 39:34-92.

Ryan, Paul. 2003. Evaluating vocationalism. European Journal of Education 38:147-162.

Sauer, Carsten, Katrin Auspurg, Thomas Hinz and Stefan Liebig. 2011. The application of factorial surveys in general population samples. The effects of respondent age and education on response times and response consistency. Survey Research Methods 5:89-102.

Statistisches Bundesamt. 2018. Auszubildende. https://www.destatis.de/DE/ZahlenFakten/ GesellschaftStaat/BildungForschungKultur/BeruflicheBildung/Tabellen/AzubiRangliste.html (Accessed: 27 November 2018).

Stiglitz, Joseph. 1975. The theory of screening, education, and the distribution of income. American Economic Review 65:283-300.

Thelen, Kathleen. 2004. How institutions evolve. The political economy of skills in Germany, Britain, the United States, and Japan. Cambridge: Cambridge University Press.

Wallander, Lisa. 2009. 25 years of factorial surveys in sociology. A review. Social Science Research 38:505-520.

Weinberg, Jill D., Jeremy Freese and David McElhattan. 2014. Comparing data characteristics and results of an online factorial survey between a population-based and a crowdsource-recruited sample. Sociological Science 1:292-310.

Zeng, Zhen, and Yu Xie. 2004. Asian-Americans' earnings disadvantage reexamined. The role of place of education. American Journal of Sociology 109:1075-1108.

Felix Stumpf 1985, Dipl.-Sozw., PhD student at the Chair of Sociology and Empirical Research Methods, University of Erlangen-Nuremberg. Research focus: Labour market and migration sociology. Publications: The Hiring Prospects of Foreign-Educated Immigrants: A Factorial Survey among German Employers. Work, Employment and Society 33, 2019 (with A. Damelang, M. Abraham and S. Ebensperger); Foreign credential recognition and immigrants' chances of being hired for skilled jobs - Evidence from a survey experiment among employers. Social Forces soz154, 2020 (online first) (with A. Damelang and S. Ebensperger). 
Andreas Damelang 1979, Dr., Senior Academic Advisor at the Chair of Sociology and Empirical Research Methods, University of Erlangen-Nuremberg. Research focus: Labour market and migration sociology. Recent publications: Die Durchlässigkeit zwischen Berufsbildung und Hochschule aus soziologischer Sicht (with M. Abraham and H. Sachse). In: Durchlässigkeit zwischen beruflicher und hochschulischer Bildung (eds. B. Hemkes, K. Wilbers and M. Heister); The Hiring Prospects of Foreign-Educated Immigrants: A Factorial Survey among German Employers. Work, Employment and Society 33, 2019 (with M. Abraham, S. Ebensperger and F. Stumpf); Berufe und Arbeitsmarkt (with M. Abraham and A. Haupt). In: Arbeitsmarktsoziologie. Wiesbaden 2018 (eds. M. Abraham and T. Hinz); Die Potenziale der Zuwanderung nutzen. In: Wertedebatte: Von Leitkultur bis kulturelle Integration. Politik \& Kultur, Zeitung des Deutschen Kulturrates. Berlin 2018 (eds. O. Zimmermann and T. Geißler); Economic consequences of occupational deregulation: Natural experiment in the German crafts. Acta Sociologica 61, 2018 (with A. Haupt and M. Abraham); Occupations as labour market institutions: Occupational regulation and its effects on job matching and occupational closure. Soziale Welt 69, 2018 (with M. Stops and M. Abraham); Foreign credential recognition and immigrants' chances of being hired for skilled jobs - Evidence from a survey experiment among employers. Social Forces soz154, 2020 (online first) (with S. Ebensperger and F. Stumpf); Gender composition of occupations and occupational characteristics: Explaining their true relationship by using longitudinal data. Social Science Research 86, 2020 (with S. Ebensperger).

Martin Abraham 1964, Dr., Professor of Sociology and Empirical Research Methods, University of Erlangen-Nuremberg. Research focus: economic and organisational sociology, labour market sociology, family and social structure. Selected recent publications: Gender differences in willingness to move for interregional job offers. Demographic Research 40, 2019 (with S. Bähr and M. Trappmann); When do firms evaluate further training measures? International Journal of Manpower 40, 2019 (with A.-C. Bächmann and M. Huber); Gerechtigkeit schlägt Effizienz: Prinzipien der regionalen Umverteilung. Sozialer Fortschritt 68, 2019 (with T. Brenner, J. Eberle, J. Gniza, I. Lehmann, S. Wardenburg and M. Wrede); Electronic monitoring at work: The role of attitudes, functions, and perceived control for the acceptance of tracking technologies. Human Resource Management Journal, 2019 (online first) (with C. Niessen, C. Schnabel, K. Lorek, V. Grimm, K. Möslein and M. Wrede); Breaking the norms: When is evading inheritance taxes socially acceptable? European Journal of Political Economy 52, 2018 (with K. Lorek, F. Richter and M. Wrede); Arbeitsmarktsoziologie: Probleme, Theorien, empirische Befunde. Wiesbaden 2018 (Ed. M. Abraham and T. Hinz).

Sabine Ebensperger 1989, M.Sc., PhD student at the Chair of Sociology and Empirical Research Methods, University of Erlangen-Nuremberg. Research focus: labour market and migration sociology. Publications: The Hiring Prospects of Foreign-Educated Immigrants: A Factorial Survey among German Employers. Work, Employment and Society 33, 2019 (with A. Damelang, M. Abraham and F. Stumpf); Foreign credential recognition and immigrants' chances of being hired for skilled jobs - Evidence from a survey experiment among employers. Social Forces soz154, 2020 (online first) (with A. Damelang and F. Stumpf); Gender composition of occupations and occupational characteristics: Explaining their true relationship by using longitudinal data. Social Science Research 86, 2020 (with A. Damelang). 